\title{
Comparative aspects of immunity and vaccination in human and bovine trichomoniasis: a review
}

\author{
Aspinas Chapwanya $^{2,3}$ • Abubakar Yusha'u Usman ${ }^{1}$ Pete Charles Irons ${ }^{1,2}$
}

\begin{abstract}
Trichomonas vaginalis and Tritrichomonas foetus are important extracellular protozoans that cause, respectively, human and bovine venereal diseases. Trichomonads are extracellular parasites that primarily inhabit the genital tracts of the mammalian hosts where they overcome the mucus barrier and parasitize mucosa by contact-dependent or contact-independent cytotoxicity. Transient immunity is usually achieved by the host after clinical infection. At present, vaccination in cattle reduces infection rates and reproductive wastage in affected herds. After vaccination, immunoglobulin $\mathrm{G}$ ( $\mathrm{IgG})$ levels increase in systemic circulation while immunoglobulin A (IgA) levels rise in the vagina. Only moderate protection is conferred by means of vaccination. Future vaccine development strategies are needed for cattle to enhance the antigenic component or use adjuvant that strongly activates the innate immune response to produce safe and potent vaccines. This paper reviews the current knowledge of the immunology of trichomoniasis infection and the challenges and potential of vaccines in the control of the infection in human and bovine trichomoniasis.
\end{abstract}

* Aspinas Chapwanya

achapwanya@rossvet.edu.kn

1 Department of Production Animal Studies, Faculty of Veterinary Science, University of Pretoria, Onderstepoort 0110, Pretoria, South Africa

2 Institute of Food, Nutrition and Well-being (IFNuW), University of Pretoria, Pretoria, South Africa

3 Ross University School of Veterinary Medicine, Box 334, Basseterre, St Kitts and Nevis, West Indies
Keywords Tritrichomonas foetus - Trichomonas vaginalis . Venereal infection · Immunity · Vaccination · Bovine . Fertility

\section{Introduction}

Trichomoniasis is an important human and bovine sexually transmitted infection (STI) caused by fastidious flagellated trichomonad protozoans in the phylum Parabasalia, order Trichomonadida, and family Trichomonadidae (Brugerolle and Lee 2000). The human pathogen, Trichomonas vaginalis, is primarily an infection of the urogenital tract residing in the vagina and urethra and causing vaginitis, cervicitis, and pregnancy losses. This perturbation of the genital cell membranes predisposes women to an increased risk of transmitting human immunodeficiency virus (HIV) (Petrin et al. 1998). Similarly, infection with Tritrichomonas foetus in cattle is devastating and causes vaginitis, cervicitis endometritis, and sub-fertility (Rhyan et al. 1988).

Morphologically, trichomonads are complex single-celled organisms that multiply by binary fission. These protozoa are approximately twice the size of white blood cells and are highly motile; Trichomonas vaginalis has four anterior flagella while Tritrichomonas foetus has three (Benchimol 2009). Both have a recurrent flagellum that runs toward the posterior region of the cell adhering to the cell body to form an undulating membrane (Honigberg 1978). Both are extracellular parasites which penetrate the mucus barrier and parasitize the genital epithelium. Cyto-adherence is necessary for pathogenicity (Arroyo et al. 1995; Mendoza-Lopez et al. 2000). In the reproductive tract, the trichomonads colonize and establish an infection by adhering to the vagina and then subsequently ascending to the cervix and uterus (Mendoza-Lopez et al. 2000). This progressive invasion of the genital tract results 
in varying degrees of inflammation with consequent transient or permanent sterility (BonDurant 1997). Although current therapies use nitroimidazole drugs in both humans and cattle to control infection, some adverse side effects, poor availability, and treatment failures are known to reduce efficacy (Kulda 1999; Wendel and Workowski 2007).

The role of acquired immunity in preventing human trichomoniasis is still not clearly understood. Some reports showed that exposures to Trichomonas vaginalis do not confer protection (Petrin et al. 1998). Repeated infections with Trichomonas vaginalis can occur without significant decrease in either the duration of infection or the severity of symptoms (Honigberg 1978; Garber and Lemchuk-Favel 1990). Recent studies proved that transient immunity can be achieved after Trichomonas vaginalis infection in women (Chang et al. 2004) and Tritrichomonas foetus infection in cows (Corbeil et al. 2008). Vaccination against Tritrichomonas foetus is beneficial in cattle because it results in formation of inductive sites for a local IgA response genital mucosa (Villarroel et al. 2004) and therefore has great potential as a strategy for combating trichomoniasis.

This review discusses the pathogenesis, the host immune responses, and the role of immunotherapy in the control of human and bovine genital trichomoniasis. The potential for the development of an effective vaccine is also highlighted.

\section{Economic importance}

About 340 million cases of human sexually transmitted infection (STI) are diagnosed annually (Garcia Vega and Puigvert Viu 2010) of which $51.2 \%$ (174 million cases) are trichomoniasis making it the most common non-viral STI in the world, particularly the developing countries (Mavedzenge et al. 2010; Onoya et al. 2012). The prevalence of Trichomonas vaginalis infection in the USA is estimated to be 2.3 million (3.1\%) among women ages 14-49 years (Sutton et al. 2007)

In cattle in the USA, Tritrichomonas foetus-infected bulls in a herd cost \$US800-6030 per bull per year (Williamson 2009; Fitzgerald 1986). Infection in cows causing early embryonic death, abortion, pyometra, or transient infertility is worth losses of \$US 60 million per annum when $25 \%$ of the herds are endemically infected (Hum 1996). The economic impact of trichomonias infection is therefore severe; the calf crop can be reduced by up to $50 \%$ in beef enterprises.

\section{Clinical manifestation in humans}

Nearly $50 \%$ of women with Trichomonas vaginalis are asymptomatic (Swygard et al. 2004, Romoren et al. 2007), and the extent of the inflammatory responses to the parasite determines severity of the symptoms. There are reports of dysuria, lower abdominal discomfort, itchiness of the vagina, leucorrhea, and vaginal odor in some women (Schwebke and Burgess 2004). Thus, Trichomonas vaginalis infection is usually only detected during routine STD screening (Bosserman et al. 2011).

Trichomoniasis is also prevalent in men, especially the partners of infected women. Unlike in women, the condition usually resolves without treatment within 2 weeks to 4 months (Krieger 1995). The high rate of asymptomatic infection in men means that many people unknowingly harbor the parasite and spread the infection within the community. It is thought that high zinc concentrations found in men may prevent Trichomonas vaginalis from being established in the male reproductive tract because Trichomonas vaginalis is readily killed at concentrations of zinc that occur in the prostatic fluid of healthy men (Langley et al. 1987).

\section{Clinical manifestation in cattle}

On the other hand, clinical outcome of Tritrichomonas foetus infection in cows includes early embryonic death, abortion, fetal macerations, and/or pyometra. Some cows, following abortion, are temporarily infertile or become carriers (Rae 1989). In contrast to humans, pregnancy losses (early embryonic death, repeat breeding, abortion) are typical clinical manifestations. Campylobacteriosis presents similar clinical signs in cows and is often confused with trichomoniasis (Dijkstra et al. 2005; Bergen et al. 2005; Hoffer 1981; Bawa et al. 1987; Hum 1987; Wittenbrink 2002). Observant owners report early return to estrus as the first clinical sign of Tritrichomonas foetus infection during the breeding season. Pyometra and fetal maceration are usually incidental findings during transrectal palpation for pregnancy diagnosis.

The absence of macroscopic and microscopic pathology and a limited immunologic response to Tritrichomonas foetus infection in bulls mean that no overt clinical signs are exhibited by infected bulls (Bondurant 2005).

\section{Pathogenesis}

The pathogenesis of trichomonad infection is not well understood (Bachmann et al. 2011; Cobo et al. 2011a, b; Hirt et al. 2011). Cyto-adherence (Alderete et al. 1995) and cytotoxicity (Petrópolis et al. 2008; Ramon-Luing Lde et al. 2011) are thought to be the principal mechanism. Binding of trichomonads to vaginal epithelial cells for colonization and infection is dependent on adhesion molecules on the surface of the parasites, either alone or with other soluble parasite molecules such as hydrolytic enzymes (Peterson and Alderete 1982; Neale and Alderete 1990; Lockwood et al. 1984; Hernandez et al. 2011), cytotoxic molecules (Ramon-Luing Lde et al. 
2011; Lucas et al. 2008), cell detaching (Garber et al. 1989), or cell lytic factors (Alvarez-Sanchez et al. 2000; Kennett et al. 2002).

In human trichomoniasis, a complex relationship between Trichomonas vaginalis growth and the Lactobacilli bacteria in the vagina is thought to influence clinical outcome (Bachmann et al. 2011; Meysick and Garber 1992). It is not clear whether Trichomonas vaginalis infection alters the vaginal microenvironment by creating an anaerobic situation or if anaerobes in the vagina precede Trichomonas vaginalis growth (Petrin et al. 1998).

In laboratory mice, Tritrichomonas foetus maintains its shape and flagella and adheres to and injure vaginal and endometrial epithelial cells (Singh et al. 2004; Gilbert et al. 2000; Midlej et al. 2009; Vilela and Benchimol 2011; Pereira-Neves et al. 2012). Inhibition of cell division and endometrial inflammation were detected in vitro in oviduct organ culture models (Benchimol et al. 2006; Ma et al. 2011) .

Tritrichomonas foetus invades bovine placental tissue (Rhyan et al. 1988) causing inflammatory changes in the endometrium and oviducts (Anderson et al. 1996). The interactions of Tritrichomonas foetus and Trichomonas vaginalis with host epithelial cells are associated with the activation of different proteases causing epithelial cell apoptosis (Midlej et al. 2009; Midlej and Benchimol 2010). In vivo, Tritrichomonas foetus initially adheres to and infects the vagina, causing vaginitis, and then ascends to the uterus and oviduct (Anderson et al. 1996; BonDurant et al. 2003) and may also cross the placenta. Trichomonads are usually confined to the lumen of the genitalia (Parsonson et al. 1976) but can adhere tightly to oviductal epithelial cells, thus preventing fertilization (Midlej et al. 2009). On the other hand, Trichomonas vaginalis causes hydrolase and endotoxin invasion of the amniotic fluid in pregnant women (McGregor et al. 1992).

In the murine model, Tritrichomonas foetus maintains its shape and flagella when invading the deeper oviduct folds which are better suited for anaerobic respiration (Monteavaro et al. 2007) while Trichomonas vaginalis assumes an amoeboid shape when adhering to epithelial cells (Gonzalez-Robles et al. 1995).

\section{Pathological signs and symptoms}

Post-insemination pyometra occurs in about $10 \%$ of the cows. Infection is established through colonization of the vagina by the trichomonad and then ascends to the uterus (Rae and Crews 2006). After an incubation period of 3-22 months, clinical signs in heifers include vaginitis; endometritis; and edema of the vulva, perivaginal tissue, and uterine wall (Parkinson 2009). Fertilization and implantation are not disturbed, but the conceptus dies around 30-50-day gestation
(Parsonson et al. 1976) while some abort as late as 5 months (Rae and Crews 2006). Many cows successfully eliminate the infection after calving (Parkinson 2009; Skirrow 1987).

Infection of the bull is venereal and asymptomatic (Parsonson et al. 1974; Rhyan et al. 1999a). Bulls 5 years or older often become lifelong carriers because the deep crypts of the penile integument and preputial mucosa provide a suitable niche for the parasite. Urethritis is sometimes seen while purulent urethritis was reported in men with acute Trichomonas vaginalis infection (Petrin et al. 1998; Abdolrasouli et al. 2007; Saleem et al. 2009; Le Roux et al. 2010).

\section{Immunization in humans}

The roles of convalescent or acquired immunity in human trichomoniasis are not clear. Repeated infections with Trichomonas vaginalis occur without a significant decrease in either the duration of infection or the intensity of symptoms as might be expected in the presence of a specific immune response (Honigberg 1978; Garber and Lemchuk-Favel 1990). Anti-Trichomonas vaginalis immunoglobulins (IgM, IgG, and IgA) titers rise after Trichomonas vaginalis infection, but there is no specific protection (Abraham et al. 1996). Although anti-trichomonal antibodies are present in human cervicovaginal secretions (Ryan et al. 2011), there is no evidence that local vaginal immunoglobulins play a role in protection against Trichomonas vaginalis infection. Thus, the role of cell-mediated immunity in vivo is not clear (Yano and Kurata 2011).

In field trials using heat-inactivated Trichomonas vaginalis vaccine prepared from inactivated lactobacilli and administered intravaginally, persistently infected women were clinically cured (Aburel et al. 1963; Milovanovic et al. 1983; Gombosova et al. 1986; Demes et al. 1985; Cudmore and Garber 2010). However, lack of antigenic similarity between the vaccine and Trichomonas vaginalis was reported (Alderete 1988) while other trials with the vaccine were inconclusive (Guerrero et al. 1987). It is not clear why this vaccine is less effective than the bovine vaccine. Infection in human and cattle needs to be further investigated.

An in vitro study showed that mice became immune when Trichomonas vaginalis was injected subcutaneously with Freund's complete adjuvant and a booster dose with the trichomonads and Freund's incomplete adjuvant (Abraham et al. 1996). Thus, systemic vaccination increased antibody (IgG) and cytokine production and increased proliferation and/or maturation of immune cells compared to vaginally infected naïve mice (Abraham et al. 1996). Vaccinating mice with Trichomonas vaginalis (subcutaneous injection of whole cells with adjuvant) protects from subsequent vaginal infection, indicating long-term immunity (Martinotti et al. 1977; Paintlia et al. 2002). Molecular expression of pro- 
inflammatory cytokines, markers for $\mathrm{T}$ regulatory and $\mathrm{T}$ helper 17 cells, as well as heme oxygenase- 1 expression in uterine tissue of BALB/c mice has demonstrated TNF- $\alpha$ augmentation in the uterus of infected animals. Anti-inflammatory cytokine IL-10 was also upregulated (Vilela and Benchimol 2013; Woudwyk et al. 2012). These studies provide new hope for development of vaccines against trichomoniasis.

Hindrance to developing solid immunity is the heterogeneous immune responses to Trichomonas vaginalis infection (Garber et al. 1986). Serum from infected women had antibodies against different protein epitopes despite receiving the same trichomonal strain (Garber et al. 1986).

Convalescent and acquired immune responses to Tritrichomonas foetus infection reveal an ability to mount innate responses by the host at a local and systemic level (Anderson et al. 1996; Clark et al. 1983a; Skirrow and BonDurant 1990; BonDurant et al. 1993; BonDurant et al. 1996; Corbeil et al. 1998). Antigen uptake by the genital epithelia is followed by formation of mucosal-associated lymphoid tissue and local IgA and IgG 1 response. In cattle, infected heifers mounted minimal systemic antibody responses but strong vaginal, cervical, and uterine IgA and IgG1 responses 7-12 weeks after an intravaginal inoculation of Tritrichomonas foetus (BonDurant et al. 1996; Corbeil et al. 1998). Thus, whole-cell and subunit vaccines provide protection when administered either systemically or intravaginally to susceptible females (Hudson et al. 1993; Corbeil 1994).

Other vaccine strains also successfully provoked both local and systemic immune responses in virgin heifers after mucosal (intravaginal/intranasal) or systemic administration (BonDurant et al. 1993; Ikeda et al. 1995; Voyich et al. 2001). TF190 adhesin, a glycoprotein surface component of Tritrichomonas foetus (Shaia et al. 1998), the immunoaffinitypurified superficial antigen Tritrichomonas foetus 1.17 (Hodgson et al. 1990), showed efficacy. Systemic immunization with these antigens produced high titers of IgG antibody and primed anamnestic mucosal IgA response in heifers challenged with Tritrichomonas foetus. Vaccinated heifers also cleared infection faster than control animals. Thus, immunoprophylaxis reduces infection rates in cattle.

Systemic vaccination with killed Tritrichomonas foetus in oil adjuvant prevents infection in bulls aged 5 years but is not protective in older bulls (Clark et al. 1983b). Recent studies show that infected bulls have significantly more IgG1, IgA, IgM, and IgG2 antibodies to Tritrichomonas foetus I.17 antigen in preputial secretions (Rhyan et al. 1999b; Cobo et al. 2010; Cobo et al. 2011a, b). However, in South Africa, attempts to use killed whole-cell TF systemic vaccination in bulls were not successful (Herr et al. 1991).

There are ongoing efforts to develop vaccines for human and bovine trichomoniasis (Cudmore and Garber 2010). In a field trial using a whole-cell vaccine, the immunity induced by the vaccine greatly reduced Tritrichomonas foetus infection and reproductive loss (Schnackel et al. 1990). The reduction in the infection rate is associated with increased local and systemic anti-trichomonal antibodies in genital tract secretions of infected heifers (BonDurant et al. 1993; Campero et al. 1999; Campero and Cobo 2006).

A commercially available monovalent vaccine containing $5 \times 10^{6}$ killed cells, whole of Tritrichomonas foetus suspended in a special oil adjuvant, is partially protective (Kvasnicka et al. 1992). A comparison of pregnancy and calving rates between beef heifers vaccinated with this vaccine and control heifers showed that twice as many vaccinated heifers calved as control animals (61 vs 31 \%) (Kvasnicka et al. 1992). The efficacy of this vaccine is yet to be tested on bulls (Bondurant 2005).

These responses to vaccination can be compared to those of bovine genital campylobacteriosis. Campylobacteriosis vaccines are available for immunotherapy and immunoprophylaxis of bovine genital campylobacteriosis (Bondurant 2005). High infection clearance rates following vaccination mean that immunotherapy of valuable bulls is clinically feasible (Bondurant 2005). The same vaccine is used prophylactically to either prevent infection or significantly reduce the persistence of infection in both bulls and cows (Cobo et al. 2011a, b; Bondurant 2005; Vasquez et al. 1983; Eaglesome et al. 1986; Corbeil et al. 2003). In addition, immunized bulls do not become permanent carriers of Campylobacter foetus venerealis.

All clinical vaccine trials show that it is beneficial to vaccinate cattle against trichomonosis (Villarroel et al. 2004; Schnackel et al. 1990; Kvasnicka et al. 1992). The promise of these current vaccines makes it imperative to continue the search for suitable vaccine immunostimulatory component, appropriate timing, and most effective and safe route of administration of vaccines to produce robust lifelong protection.

Acknowledgments Funds were provided by the Institute of Food, Nutrition and Well-being (IFNuW) from the University of Pretoria, South Africa.

Conflict of interest The authors (Aspinas Chapwanya, Abubakar Y Usman, Pete Irons) have no financial or personal relationship with other people or organizations that could inappropriately influence or bias the paper entitled "Comparative aspects of immunity and vaccination in human and bovine trichomoniasis: a review."

\section{References}

Abdolrasouli, A., Amin, A., Baharsefat, M., Roushan, A. \& Mofidi, S. 2007.Persistent urethritis and prostatitis due to Trichomonas vaginalis: A case report. The Canadian Journal of Infectious Diseases and Medical Microbiology / AMMI Canada. 18, 5, 308310. 
Abraham, M.C., Desjardins, M., Filion, L.G. \& Garber, G.E. 1996. Inducible immunity to Trichomonas vaginalis in a mouse model of vaginal infection. Infection and Immunity. 64, 9, 3571-3575.

Aburel, E., Zervos, G., Titea, V. \& Pana, S. 1963. Immunological and Therapeutic Investigations in Vaginal Trichomoniasis. Rumanian Medical Review, 84, 13-19.

Alderete, J.F. 1988. Does lactobacillus vaccine for trichomoniasis, Solco Trichovac, induce antibody reactive with Trichomonas vaginalis? Genitourinary Medicine. 64,2, 118-123.

Alderete, J.F., O'Brien, J.L., Arroyo, R., Engbring, J.A., Musatovova, O., Lopez, O., Lauriano, C. \& Nguyen, J. 1995. Cloning and molecular characterization of two genes encoding adhesion proteins involved in Trichomonas vaginalis cytoadherence. Molecular Microbiology. 17, 1, 69-83.

Alvarez-Sanchez, M.E., Avila-Gonzalez, L., Becerril-Garcia, C., FattelFacenda, L.V., Ortega-Lopez, J. \& Arroyo, R. 2000. A novel cysteine proteinase (CP65) of Trichomonas vaginalis involved in cytotoxicity. Microbial Pathogenesis. 28, 4, 193-202.

Anderson, M.L., BonDurant, R.H., Corbeil, R.R. \& Corbeil, L.B. 1996. Immune and inflammatory responses to reproductive tract infection with Tritrichomonas foetus in immunized and control heifers. Journal of Parasitology. 82, 4, 594-600.

Arroyo, R., Engbring, J., Nguyen, J., Musatovova, O., Lopez, O., Lauriano, C. \& Alderete, J.F. 1995. Characterization of cDNAs encoding adhesin proteins involved in Trichomonas vaginalis cytoadherence. Archives of Medical Research. 26. 4, 361-369.

Bachmann, L.H., Hobbs, M.M., Sena, A.C., Sobel, J.D., Schwebke, J.R., Krieger, J.N., McClelland, R.S. \& Workowski, K.A. 2011. Trichomonas vaginalis genital infections: progress and challenges. Clinical Infectious Diseases. 53, Suppl 3, S160-72.

Bawa, E.K., Voh, A.A., Oyedipe, E.O., Adekeye, J.O., Dawuda, P.M. \& Rekwot, P.I. 1987. Campylobacteriosis and bovine infertility and abortion in an artificial insemination programme in Nigeria. Veterinary Record. 120, 20, 483.

Benchimol, M. 2009. The cytoskeleton of trichomonads, in: Trends in Cell and Molecular Biology, 4 Research Trends, Trivandrum, 2539.

Benchimol, M., Dias, A.B. \& Fontes, R. 2006. Interaction of Tritrichomonas foetus and the bovine oviduct in an organ culture model. Veterinary Parasitology. 140,3, 244-250.

Bergen, M.A.P., Linnane, S., Putten, J.P.M. \& Wagenaar, J.A. 2005. Global detection and identification of Campylobacter fetus subsp. venerealis Revue Scientifique et Technique - Office International des Épizooties. 24, 3, 1017-1026.

BonDurant, R.H. 1997. Pathogenesis, diagnosis, and management of Trichomoniasis in cattle. The Veterinary clinics of North America Food Animal Practice. 13, 2, 345-361.

Bondurant, R.H. 2005. Venereal diseases of cattle: natural history, diagnosis, and the role of vaccines in their control. The Veterinary Clinics of North America Food Animal Practice. 21, 2, 383-408.

BonDurant, R.H., Corbeil, R.R. \& Corbeil, L.B. 1993. Immunization of virgin cows with surface antigen TF1.17 of Tritrichomonas foetus. Infection and Immunity. 61, 4,1385-1394

BonDurant, R.H., Hoosear, K.A., Corbeil, L.B. \& Bernoco, D. 1996. Serological response to in vitro-shed antigen(s) of Tritrichomonas foetus in cattle. Clinical and Diagnostic Laboratory Immunology. 3, 4, 432-437.

BonDurant, R.H., Campero, C.M., Anderson, M.L. \& Hoosear, K.A. 2003. Detection of Tritrichomonas foetus by polymerase chain reaction in cultured isolates, cervicovaginal mucus, and formalin-fixed tissues from infected heifers and fetuses. Journal of Veterinary Diagnostic Investigation. 15, 6, 579-584.

Bosserman, E.A., Helms, D.J., Mosure, D.J., Secor, W.E. \& Workowski, K.A. 2011. Utility of Antimicrobial Susceptibility Testing in Trichomonas vaginalis-Infected Women With Clinical Treatment Failure. Sexually Transmitted Diseases. 38, 10, 983-987.
Brugerolle, G. \& Lee, J.J. 2000. Phylum Parabasalia, in: Lee, J.J., G.F. Leedale \& P. Bradbury, 2nd edn, Allen Press, Lawrence. p, pp.11961250 .

Campero, C.M. \& Cobo, E.R. 2006. Tritrichomonas foetus: pathogenesis of embryo/fetal mortality, antigenic vaccine characterization and immune induced response. Revista de Medicina Veterinaria (Buenos Aires). 87, 2, 47-56.

Campero, C.M., Rossetti, O., Medina, D., Bretschneider, G. \& Roppel, M.K. 1999. Immunization of heifers with a Tritrichomonas foetus membrane vaccine. Veterinaria Argentina. 16, 154, 250-262.

Chang, J. H., Ryang, Y.S., Morio, T., Lee, S.K., \& Chang, E.J. 2004. Trichomonas vaginalis inhibits proinflammatory cytokine production in macrophages by suppressing NF-kappaB activation. Molecules and Cells. 18, 2, 177-785.

Clark, B.L., Dufty, J.H. \& Parsonson, I.M. 1983a.The effect of Tritrichomonas foetus infection on calving rates in beef cattle. Australian Veterinary Journal. 60, 3, 71-74.

Clark, B.L., Dufty, J.H. \& Parsonson, I.M. 1983b. Immunisation of bulls against trichomoniasis. Australian Veterinary Journal. 60, 6, 178179.

Cobo, E.R., Corbeil, L.B., Gershwin, L.J. \& BonDurant, R.H. 2010. Preputial cellular and antibody responses of bulls vaccinated and/ or challenged with Tritrichomonas foetus. Vaccine, 28, 2, 361-670.

Cobo, E.R., Corbeil, L.B. \& BonDurant, R.H. 2011. Immunity to infections in the lower genital tract of bulls. Journal of Reproductive Immunology, 89, 1, 55-61.

Cobo, E.R., Eckmann, L. \& Corbeil, L.B. 2011. Murine models of vaginal trichomonad infections. The American Journal of Tropical Medicine and Hygiene. 85, 4, 667-673.

Corbeil, L.B. 1994. Vaccination strategies against Tritrichomonas foetus. Parasitology today (Personal ed.), 10, 3, 103-106.

Corbeil, L.B., Anderson, M.L., Corbeil, R.R., Eddow, J.M. \& BonDurant, R.H. 1998. Female reproductive tract immunity in bovine trichomoniasis. American Journal of Reproductive Immunology (New York, N.Y.: 1989). 39, 3, 189-198.

Corbeil, L.B., Campero, C.M., Rhyan, J.C. \& BonDurant, R.H. 2003. Vaccines against sexually transmitted diseases. Reproductive Biology and Endocrinology. 1, 118.

Corbeil, L.B., Campero, C.M., Hoosear, K.V. \& BonDurant, R.H. 2008 Detection of trichomonad species in the reproductive tracts of breeding and virgin bulls. Veterinary Parasitology. 154, 226-232.

Cudmore, S.L. \& Garber, G.E. 2010. Prevention or treatment: the benefits of Trichomonas vaginalis vaccine. Journal of Infection and Public Health. 3, 2, 47-53.

Demes, P., Gombosova, A. \& Valent, M. 1985. SolcoTrichovac-a new trend in the immunotherapy of urogenital trichomoniasis? Czech Republic Gynaecology. 50, 7, 505-509.

Dijkstra, T., Wagenaar, J.A., Visser, I.J., van Bergen, M.A., Pastoor, P.W., Strampel, J. \& Kock, P.A. 2005. Campylobacter as a venereal disease in cattle. Tijdschrift Voor Diergeneeskunde. 130, 13, 407-408.

Eaglesome, M.D., Garcia, M.M., Hawkins, C.F. \& Alexander, F.C. 1986. Vaccination studies for the control of campylobacteriosis in Jamaican cattle. The Veterinary Record. 119, 12, 299-301.

Fitzgerald, P.R. 1986. Bovine trichomoniasis. The Veterinary Clinics of North America Food Animal Practice. 2, 2, 277-282.

Garber, G.E. \& Lemchuk-Favel, L.T. 1990. Association of production of cell-detaching factor with the clinical presentation of Trichomonas vaginalis. Journal of Clinical Microbiology. 28,11, 2415-2417.

Garber, G.E., Proctor, E.M. \& Bowie, W.R. 1986. Immunogenic proteins of Trichomonas vaginalis as demonstrated by the immunoblot technique. Infection and Immunity. 51, 1, 250-253.

Garber, G.E., Lemchuk-Favel, L.T. \& Bowie, W.R. 1989. Isolation of a cell-detaching factor of Trichomonas vaginalis. Journal of Clinical Microbiology. 27, 7, 1548-1553.

Garcia Vega, E.M. \& Puigvert Viu, N. 2010. Sexual transmission infections. Revista de Enfermeria (Barcelona, Spain). 33, 4, 42-46. 
Gilbert, R.O., Elia, G., Beach, D.H., Klaessig, S. \& Singh, B.N. 2000. Cytopathogenic effect of Trichomonas vaginalis on human vaginal epithelial cells cultured in vitro. Infection and Immunity. 68, 7, 4200-4206.

Gombosova, A., Demes, P. \& Valent, M. 1986. Immunotherapeutic effect of the lactobacillus vaccine, Solco Trichovac, in trichomoniasis is not mediated by antibodies cross reacting with Trichomonas vaginalis. Genitourinary Medicine. 62, 2,107-110.

Gonzalez-Robles, A., Lazaro-Haller, A., Espinosa-Cantellano, M., Anaya-Velazquez, F. \& Martinez-Palomo, A. 1995. Trichomonas vaginalis: ultrastructural bases of the cytopathic effect. The Journal of Eukaryotic Microbiology. 42,5, 641-651.

Guerrero, B., Millan, R., Jorquera, A. \& Faundez, R. 1987. Vaccination with SolcoTrichovac in vaginal trichomoniasis. Revista Chilena de Obstetricia Ginecologia. 52, 3, 193-197.

Hernandez, H.M., Sariego, I., Alvarez, A.B., Marcet, R., Vancol, E., Alvarez, A., Figueredo, M. \& Sarracent, J. 2011. Trichomonas vaginalis $62 \mathrm{kDa}$ proteinase as a possible virulence factor. Parasitology Research. 108,1, 241-245.

Herr, S., Ribeiro, L.M.M., Claassen, E. \& Myburgh, J.G. 1991. A reduction in the duration of infection with Tritrichomonas foetus following vaccination in heifers and the failure to demonstrate a curative effect in infected bulls. Onderstepoort Journal of Veterinary Research. 58, 1, 41-45.

Hirt, R.P., de Miguel, N., Nakjang, S., Dessi, D., Liu, Y.C., Diaz, N., Rappelli, P., Acosta-Serrano, A., Fiori, P.L. \& Mottram, J.C. 2011. Trichomonas vaginalis pathobiology new insights from the genome sequence. Advances in Parasitology. 77, 87-140.

Hodgson, J.L., Jones, D.W., Widders, P.R. \& Corbeil, L.B. 1990. Characterization of Tritrichomonas foetus antigens by use of monoclonal antibodies. Infection and Immunity. 58, 9,3078-3083.

Hoffer, M.A. 1981. Bovine campylobacteriosis: a review. The Canadian Veterinary Journal. 22, 11,327-330.

Honigberg, B.M. 1978. Trichomonads of veterinary importance. Academic Press, Inc, New York, USA \& London.

Hudson, D.B., Ball, L., Cheney, J.M., Mortimer, R.G., Bowen, R.A., Marsh, D.J. \& Peetz, R.H. 1993. Testing of trichomoniasis vaccine in heifers mated to infected bulls. Theriogenology. 39, 4, 937-943.

Hum, S. 1987. Bovine abortion due to Campylobacter fetus. Australian Veterinary Journal, vol. 64, no. 10, pp. 319-320.

Hum, S. (ed) 1996, Bovine venereal campylobacteriosis: A diagnostic and economic perspective, In: Newell, DG;JM Ketley; RA Feldman, Eds. Campylobacter, Helicobacters and related organisms, 1 st edn, plenum press, New York.

Ikeda, J.S., BonDurant, R.H. \& Corbeil, L.B. 1995. Bovine vaginal antibody responses to immunoaffinity-purified surface antigen of Tritrichomonas foetus. Journal of Clinical Microbiology. 33, 5, $1158-1163$

Kennett, M.J. \& Hook, R.R., J. 2002. Tritrichomonas foetus: characterization of isolates and partial purification of a secreted cytotoxin. Experimental Parasitology. 102,1, 1-8.

Krieger, J.N. 1995. Trichomoniasis in men: old issues and new data. Sexually Transmitted Diseases. 22, 2, 83-96.

Kulda, J. 1999. Trichomonads, hydrogenosomes and drug resistance. International Journal for Parasitology. 29, 2,199-212.

Kvasnicka, W.G., Hanks, D., Huang, J.C., Hall, M.R., Sandblom, D., Chu, H.J., Chavez, L. \& Acree, W.M. 1992. Clinical evaluation of the efficacy of inoculating cattle with a vaccine containing Tritrichomonas foetus. American Journal of Veterinary Research. 53, 11, 2023-2027.

Langley, J.G., Goldsmid, J.M. and Davies, N. 1987. Venereal trichomoniasis: role of men. Genitourinary Medicine. 63(4): 264-267.

Le Roux, M.C., Ramoncha, M.R., Adam, A. \& Hoosen, A.A. 2010. Aetiological agents of urethritis in symptomatic South African men attending a family practice. International Journal of STD \& AIDS. 21, 7, 477-481.
Lockwood, B.C., North, M.J. \& Coombs, G.H. 1984. Trichomonas vaginalis, Tritrichomonas foetus, and Trichomitus batrachorum: comparative proteolytic activity. Experimental Parasitology. 58, 3, $245-253$.

Lucas, J.J., Hayes, G.R., Kalsi, H.K., Gilbert, R.O., Choe, Y., Craik, C.S. \& Singh, B.N. 2008. Characterization of a cysteine protease from Tritrichomonas foetus that induces host-cell apoptosis. Archives of Biochemistry and Biophysics. 477, 2, 239-243.

Ma, L., Meng, Q., Cheng, W., Sung, Y., Tang, P., Hu, S. \& Yu, J. 2011. Involvement of the GP63 protease in infection of Trichomonas vaginalis. Parasitology Research. 109, 1, 71-79.

Martinotti, M.G., Cagliani, I., Lattes, C. \& Cappuccinelli, P. 1977. Immune response and degree of protection in mice immunized with Trichomonas vaginalis antigen. Giornale di Batteriologia, Virologia Ed Immunologia. 70, 1-6, 3-12.

Mavedzenge, S.N., Pol, B., Cheng, H., Montgomery, E.T., Blanchard, K., Bruyn, G., Ramjee, G. \& Straten, A. 2010. Epidemiological synergy of Trichomonas vaginalis and HIV in Zimbabwean and South African Women. Sexually Transmitted Diseases. 37, 7, 460-466.

McGregor, J.A., French, J.I., Jones, W., Parker, R., Patterson, E. \& Draper, D. 1992. Association of cervicovaginal infections with increased vaginal fluid phospholipase A2 activity. American Journal of Obstetrics and Gynecology. 167, 6, 1588-1594.

Mendoza-Lopez, M.R., Becerril-Garcia, C., Fattel-Facenda, L.V., AvilaGonzalez, L., Ruiz-Tachiquin, M.E., Ortega-Lopez, J. \& Arroyo, R. 2000. CP30, a cysteine proteinase involved in Trichomonas vaginalis cytoadherence. Infection and Immunity. 68, 9, 4907-4912.

Meysick, K.C. \& Garber, G.E. 1992. Interactions between Trichomonas vaginalis and vaginal flora in a mouse model. The Journal of Parasitology. 78,1, 157-160.

Midlej, V. \& Benchimol, M. 2010. Trichomonas vaginalis kills and eats-evidence for phagocytic activity as a cytopathic effect. Parasitology. 137, 1, 65-76.

Midlej, V., Vilela, R., Dias, A.B. \& Benchimol, M. 2009. Cytopathic effects of Tritrichomonas foetus on bovine oviduct cells. Veterinary Parasitology. 165, 3-4, 216-230.

Milovanovic, R., Grcic, R. \& Stojkovic, L. 1983. Serological study with SolcoTrichovac, a vaccine against Trichomonas vaginalis infection in women. Gynakologische Rundschau. 23, Suppl 2, 39-45.

Monteavaro, C.E., Aguirre, J.I., Soto, P., Echevarría, H.M., Catena, M.C., Portiansky, E.L. \& Gimeno, E.J. 2007. Interaction of Tritrichomonas foetus with the reproductive tract of experimentally infected female BALB/c mice: ultrastructural evaluation. Veterinary Journal. 173, 1, 204-208.

Neale, K.A. \& Alderete, J.F. 1990. Analysis of the proteinases of representative Trichomonas vaginalis isolates. Infection and Immunity. $58,1,157-162$.

Onoya, D., Reddy, P., Sifunda, S., Lang, D., Wingood, G.M., van den Borne, B. \& Ruiter, R.A. 2012. Transactional Sexual Relationships, Sexually Transmitted Infection Risk, and Condom Use Among Young Black Women in Peri-Urban Areas of the Western Cape Province of South Africa. Women's health issues: Official Publication of the Jacobs Institute of Women's Health.

Paintlia, M.K., Kaur, S., Gupta, I., Ganguly, N.K., Mahajan, R.C. \& Malla, N. 2002. Specific IgA response, T-cell subtype and cytokine profile in experimental intravaginal trichomoniasis. Parasitology Research. 88, 4, 338-343.

Parkinson, T.J. 2009. Specific infectious diseases causing infertility and subfertility in cattle. in: D.E. Noakes, T.J. Parkinson \& G.C.W. England. Veterinary Reproduction and Obstetrics. 9th edn, Sounders Elsevier, Edinburgh, pp. 477-517.

Parsonson, I.M., Clark, B.L. \& Dufty, J. 1974. The pathogenesis of Tritrichomonas foetus infection in the bull. Australian Veterinary Journal. 50,10, 421-423. 
Parsonson, I.M., Clark, B.L. \& Dufty, J.H. 1976. Early pathogenesis and pathology of Tritrichomonas foetus infection in virgin heifers. Journal of Comparative Pathology. 86,1, 59-66.

Pereira-Neves, A., Nascimento, L.F. \& Benchimol, M. 2012. Cytotoxic Effects Exerted by Tritrichomonas foetus Pseudocysts. Protist.

Peterson, K.M. \& Alderete, J.F. 1982. Host plasma proteins on the surface of pathogenic Trichomonas vaginalis. Infection and Immunity. 37, $2,755-762$

Petrin, D., Delgaty, K., Bhatt, R. \& Garber, G. 1998. Clinical and microbiological aspects of Trichomonas vaginalis. Clinical Microbiology Reviews. 11, 2, 300-317.

Petrópolis, D.B., Rodrigues, J.C.F., Rocha-Azevedo, B. \& Costa, e.S.F. 2008. The binding of Tritrichomonas foetus to immobilized laminin1 and its role in the cytotoxicity exerted by the parasite. Microbiology. 154, 8, 2283-2290.

Rae, D.O. 1989. Impact of trichomoniasis on the cow-calf producer's profitability. Journal of the American Veterinary Medical Association. 194,6, 771-775.

Rae, D.O. \& Crews, J.E. 2006. Tritrichomonas foetus. The Veterinary clinics of North America Food Animal Practice. 22,3, 595-611.

Ramon-Luing Lde, L., Rendon-Gandarilla, F.J., Puente-Rivera, J., AvilaGonzalez, L. \& Arroyo, R. 2011. Identification and characterization of the immunogenic cytotoxic TvCP39 proteinase gene of Trichomonas vaginalis. The International Journal of Biochemistry \& Cell Biology. 43,10,1500-1511.

Rhyan, J.C., Stackhouse, L.L. \& Quinn, W.J. 1988. Fetal and placental lesions in bovine abortion due to Tritrichomonas foetus. Veterinary Pathology. 25, 5, 350-355.

Rhyan, J.C., Wilson, K.L., Wagner, B., Anderson, M.L., BonDurant, R.H., Burgess, D.E., Mutwiri, G.K. \& Corbeil, L.B. 1999a. Demonstration of Tritrichomonas foetus in the external genitalia and of specific antibodies in preputial secretions of naturally infected bulls. Veterinary Pathology. 36,5, 406-411.

Rhyan, J.C., Wilson, K.L., Wagner, B., Anderson, M.L., BonDurant, R.H., Burgess, D.E., Mutwiri, G.K. \& Corbeil, L.B. 1999b. Demonstration of Tritrichomonas foetus in the external genitalia and of specific antibodies in preputial secretions of naturally infected bulls. Veterinary Pathology. 36,5, 406-411.

Romoren, M., Velauthapillai, M., Rahman, M., Sundby, J., Klouman, E. \& Hjortdahl, P. 2007. Trichomoniasis and bacterial vaginosis in pregnancy: inadequately managed with the syndromic approach. Bulletin of the World Health Organization. 85, 4, 297-304.

Ryan, C.M., de Miguel, N. \& Johnson, P.J. 2011. Trichomonas vaginalis: current understanding of host-parasite interactions. Essays in Biochemistry. 51,161-175.

Saleem, K., Mumtaz, B. \& Raza, N. 2009. A clinicopathological study of urethritis in males. Pakistan Journal of the College of Physicians and Surgeons. vol. 19, no. 12, pp. 772-775.

Schnackel, J.A., Wallace, B.L., Kvasnicka, W.G., Hanks, D.R. \& Hall, M.R. 1990. Trichomonas foetus vaccine immunogenicity trial. AgriPractice. 10, 6, 11-14.

Schwebke, J.R. \& Burgess, D. 2004. Trichomoniasis. Clinical Microbiology Reviews. 17, 4, 794-803.

Shaia, C.I., Voyich, J., Gillis, S.J., Singh, B.N. \& Burgess, D.E. 1998. Purification and expression of the Tf190 adhesin in Tritrichomonas foetus. Infection and Immunity. 66, 3, 1100-1105.
Singh, B.N., Lucas, J.J., Hayes, G.R., Kumar, I., Beach, D.H., Frajblat, M., Gilbert, R.O., Sommer, U. \& Costello, C.E. 2004. Tritrichomonas foetus induces apoptotic cell death in bovine vaginal epithelial cells. Infection and Immunity. 72,7, 4151-4158.

Skirrow, S. 1987. Identification of trichomonad-carrier cows. Journal of the American Veterinary Medical Association, vol. 191, no. 5, pp. 553-554.

Skirrow, S.Z. \& BonDurant, R.H. 1990. Induced Tritrichomonas foetus infection in beef heifers. Journal of the American Veterinary Medical Association. 196, 6, 885-889.

Sutton M, Sternberg M, Koumans EH, McQuillan G, Berman S, Markowitz L.2007. The prevalence of Trichomonas vaginalis infection among reproductive-age women in the United States, 20012004. Clinical Infectious Diseases. 45(10):1319-26

Swygard, H., Sena, A.C., Hobbs, M.M. \& Cohen, M.S. 2004. Trichomoniasis: clinical manifestations, diagnosis and management. Sexually Transmitted Infections. 80, 2, 91-95.

Vasquez, L.A., Ball, L., Bennett, B.W., Rupp, G.P., Ellis, R., Olson, J.D. \& Huffman, M.H. 1983. Bovine genital campylobacteriosis (vibriosis): vaccination of experimentally infected bulls. American Journal of Veterinary Research. 44, 8,1553-1557.

Vilela, R.C. \& Benchimol, M. 2011. Interaction of Trichomonas vaginalis and Tritrichomonas foetus with keratin: an important role in parasite infection. Memorias do Instituto Oswaldo Cruz, vol. 106, no. 6, pp. 701-704.

Vilela, R.C. \& Benchimol, M. 2013. IL-10 release by bovine epithelial cells cultured with Trichomonas vaginalis and Tritrichomonas foetus. Memorias do Instituto Oswaldo Cruz, vol. 108, no. 1, pp. 110-112.

Villarroel, A., Carpenter, T.E. \& BonDurant, R.H. 2004. Development of a simulation model to evaluate the effect of vaccination against Tritrichomonas foetus on reproductive efficiency in beef herds. American Journal of Veterinary Research. 65, 6, 770-775.

Voyich, J.M., Ansotegui, R., Swenson, C., Bailey, J. \& Burgess, D.E. 2001. Antibody responses of cattle immunized with the Tf190 adhesin of Tritrichomonas foetus. Clinical and Diagnostic Laboratory Immunology. 8, 6, 1120-1125.

Wendel, K.A. \& Workowski, K.A. 2007.Trichomoniasis: challenges to appropriate management. Clinical infectious diseases: An Official Publication of the Infectious Diseases Society of America. 44, Suppl 3, S123-9.

Williamson, S.H. 2009. Six ways to compute the relative value of a U.S dollar amount, 1790 to present. Measuring Worth. http://www. measuringworth.com/uscompare/.

Wittenbrink, M.M. 2002. Campylobacter: prevalence and pathogenic significance in man and animals. Mitteilungen aus Lebensmitteluntersuchung und Hygiene. 93, 1, 4-8.

Woudwyk, M.A., Monteavaro, C.E., Jensen, F., Soto, P., Barbeito, C.G. \& Zenclussen, A.C. 2012. Study of the Uterine Local Immune Response in a Murine Model of Embryonic Death Due to Tritrichomonas foetus. American Journal of Reproductive Immunology (New York, N.Y.: 1989).

Yano, T. \& Kurata, S. 2011. Intracellular recognition of pathogens and autophagy as an innate immune host defence. Journal of Biochemistry. 150, 2, 143-149. 